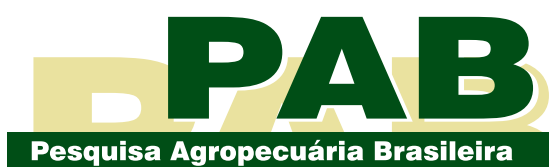

ISSN 1678-3921

Journal homepage: www.embrapa.br/pab

For manuscript submission and journal contents, access: www.scielo.br/pab

\title{
Morphometric measurements for sexual dimorphism in the Campolina horse breed
}

\begin{abstract}
The objective of this work was to distinguish the sexual dimorphism of horses of the Campolina breed, by morphometric measurements, and to classify them according to sex, using discriminating functions. Two-hundred and fifteen horses were measured, and 39 morphometric measurements were evaluated. The analysis of covariance and the discriminant analysis were performed. Males were taller and showed a wider chest, a greater scapularhumeral angle, and a larger neck, both in length and circumference. Females had a larger heart girth, wider hips, and a greater opening of the coxal-ground and femorotibial angles. Regarding classification, circumference measurements $(85.58 \%)$ were more accurate in sexual differentiation than the linear $(83.26 \%)$ and angular $(73.02 \%)$ ones. As to classification error, of the total animals measured, 10 to $20 \%$ of the females were categorized as males. In addition, 11 to $38 \%$ of the males were categorized as females. It can be concluded that of the 39 morphometric measurements evaluated, 22 are responsible for sexual dimorphism in the Campolina horse breed. Circumference and linear measurements provide a more assertive classification to determine sexual dimorphism. Angular measurements show greater classification errors regarding the gender of the horses.
\end{abstract}

Index terms: Equus caballus, equine morphology, multivariate analysis.

\section{Medidas morfométricas para o dimorfismo sexual em equinos da raça Campolina}

Resumo - O objetivo deste trabalho foi distinguir o dimorfismo sexual de equinos da raça Campolina, por meio de medidas morfométricas, e classificálos quanto ao sexo, tendo-se utilizado funções discriminantes. Foram mensurados 215 equinos, e avaliadas 39 medidas morfométricas. Realizaramse análises de covariância e discriminante. Os machos foram mais altos e apresentaram peito mais largo, maior ângulo escapulo-umeral e maior pescoço, tanto em comprimento quanto em perímetro. As fêmeas apresentaram maior perímetro torácico, ancas mais largas e maior abertura dos ângulos coxo-solo e femorotibial. Em relação à classificação, as medidas de perímetros $(85,58 \%)$ foram mais acuradas na diferenciação sexual do que as lineares $(83,26 \%)$ e as angulares $(73,02 \%)$. Quanto ao erro de classificação, do total de animais mensurados, de 10 a $20 \%$ das fêmeas foram categorizadas como machos. Além disso, de 11 a $38 \%$ dos machos foram categorizados como fêmeas. Conclui-se que, das 39 medidas morfométricas avaliadas, 22 são responsáveis pelo dimorfismo sexual em equinos da raça Campolina. As medidas de perímetros e lineares fornecem classificação mais assertiva para determinar o dimorfismo sexual. As medidas angulares mostram maiores erros de classificação em relação ao sexo dos equinos.

Termos para indexação: Equus caballus, morfologia de equino, análise multivariada. 


\section{Introduction}

The Campolina horse (Equus caballus) breed originated in 1870, in Brazil. The aim was to produce large animals with a smooth and comfortable gait, known as "marcha", which has no moments of suspension. (ABCCCampolina, 2018). For market appeal, the morphology of the Campolina horse underwent several changes that resulted in a modified conformation and increased functionality (Lucena et al., 2015).

The body dimensions and proportions of males and females differ, being called sexual dimorphism (Purzyc et al., 2011). In gait and morphology competitions of Brazilian breeds such as Mangalarga Marchador, Campolina and Mangalarga, the horses compete in separate categories according to sex and age. In these breeds, sexual dimorphism is so highly valued that breeder associations encourage leaving the mane of male horses long and clipping the mane of females, so their sex can be quickly identified visually (ABCCCampolina, 2018; ABCCMM, 2019; ABCCRMangalarga, 2020).

Phenotypic assessment, which allows characterizing the masculinity and femininity of horses without observing their reproductive system, can be carried out by evaluating morphometric measurements (Pinto et al., 2008). However, not all of these measurements are differentiated between sexes according to breed standards. In the Campolina breed, wither height and croup height are used for this distinction (ABCCCampolina, 2018). However, in the Brazilian Sport Horse and Criollo breeds, in addition to these two measurements, heart girth and fore cannon circumference are also used (ABCCH, 2020; ABCCCrioulos, 2020).

Studies have assessed sexual dimorphism in horses of different breeds from all over the world, including Thoroughbred, Arab-Barbe, Mangalarga Marchador, Hucul, Minahasa, and Lipizzan (Hintz et al., 1979; Boujenane et al., 2008; Pinto et al., 2008; Purzyc et al., 2011; Takaendengan et al., 2011; Važić et al., 2016). These works were conducted from horse birth to adulthood and showed how body indices, morphometric measurements, and even performance during obstacle jumping can define sexual traits. However, there are no known studies that use discriminant analyses to evaluate or classify sexual dimorphism in Campolina horses through morphometric measurements.
One of the classification tools that can be applied for sexual differentiation is the discriminant analysis, a multivariate analysis used to distinguish groups within a population (Härdle \& Simar, 2015). The discriminant analysis has already been used to assess sexual dimorphism in the Mangalarga Marchador and Hucul horse breeds (Pinto et al., 2008; Purzyc et al., 2011).

The objective of this work was to distinguish the sexual dimorphism of horses of the Campolina breed, by morphometric measurements, and to classify them according to sex, using discriminant functions.

\section{Materials and Methods}

Between 2016 and 2019, measurements were taken from 215 horses, consisting of 131 females and 84 males registered according to the statute of Associação Brasileira dos Criadores do Cavalo Campolina (ABCCCampolina, 2018), the Brazilian association of Campolina horse breeders. All animals were older than 36 months and originated from the Brazilian states of Rio de Janeiro, Minas Gerais, and Bahia. The research project was approved by the ethics committee on animal use of Universidade Federal Rural do Rio de Janeiro, under number 23083.013935/2017-35.

The horses were measured in a stance position, on a flat surface. The morphometric measurements were always taken on the right side of the animal, by the same trained team. As adapted from Pinto et al. (2008) and Sousa et al. (2018), 39 morphometric measurements (linear, circumferential, and angular) were taken (Figure 1), using the following equipment: hypometer and measuring tape for linear measurements; measuring tape for circumferences; and goniometer for angular measurements. The linear measurements assessed were: wither height, croup height, chest depth, body length, head length, ear length, ear width, neck length, shoulder length, arm length, forearm length, fore cannon length, fore pastern length, croup length, thigh length, leg length, hind cannon length, hind pastern length, shoulder-fetlock distance, sternum-ground distance, chest width, and hip width. The circumferential measurements evaluated were: heart girth, cranial neck circumference, caudal neck circumference, forehead circumference, nasal bridge circumference, forearm circumference, knee circumference, fore cannon circumference, fore fetlock 
circumference, and fore pastern circumference. The angular measurements studied were: scapula-ground angle, scapulohumeral angle, humeroradial angle, coxal-ground angle, coxofemoral angle, femorotibial angle, and tibiometatarsal angle.
To compare the means of the morphometric measurements between the sexes, the covariance analysis was performed, followed by Tukey's test, at $5 \%$ probability, using the RStudio software (Faraway, 2014). The following model was applied:

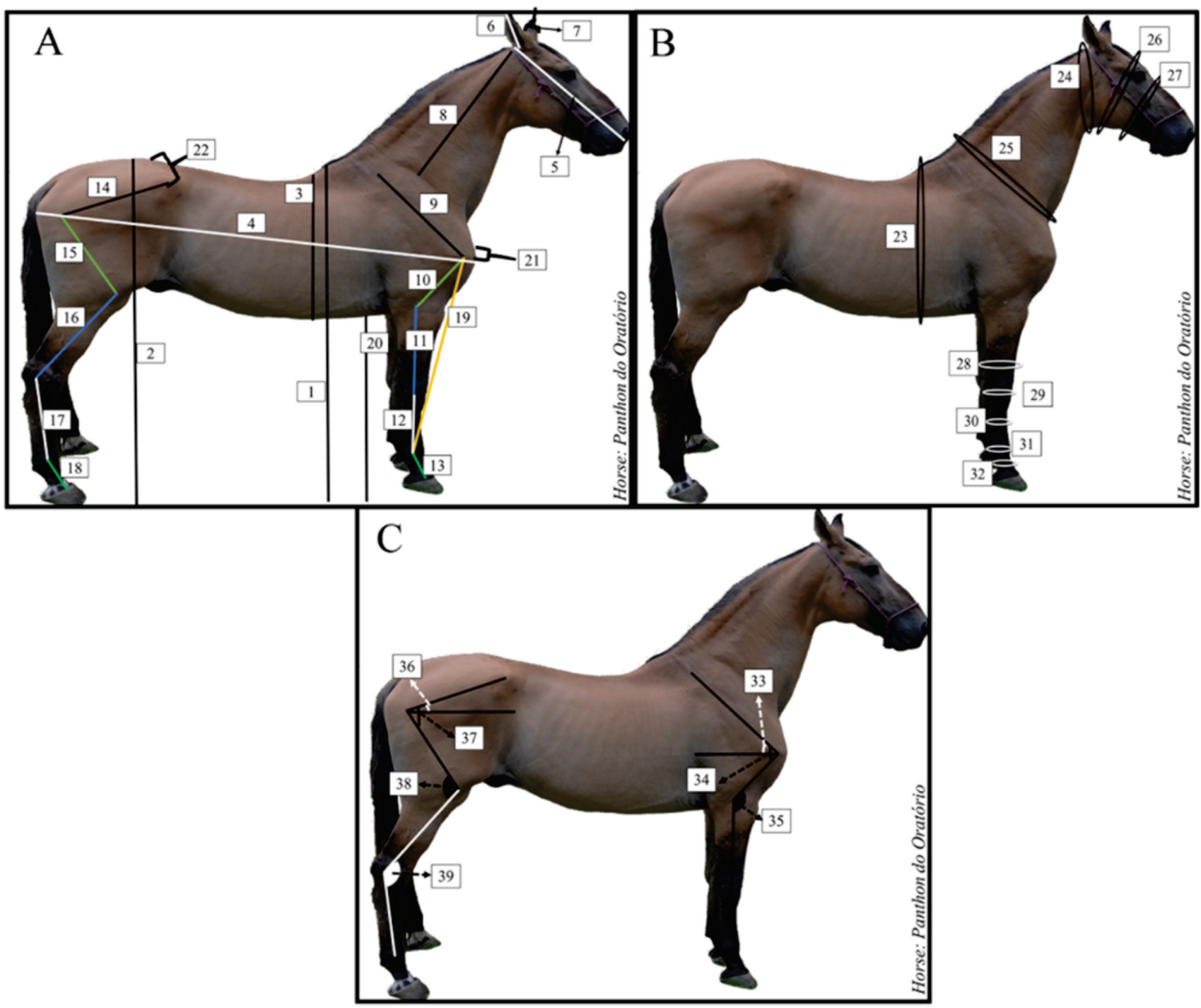

Figure 1. Illustration of the morphometric measurements taken from the Campolina (Equus caballus) horse breed in Brazil, in 2016-2019. A, linear measurements (1-22); B, circumferential measurements (23-32); and C, angular measurements (33-39). 1, wither height; 2, croup height; 3, chest depth; 4, body length; 5, head length; 6, ear length; 7, ear width; 8, neck length; 9, shoulder length; 10, arm length; 11, forearm length; 12, fore cannon length; 13, fore pastern length; 14, croup length; 15, thigh length; 16, leg length; 17, hind cannon length; 18, hind pastern length; 19, shoulder-fetlock distance; 20, sternum-ground distance; 21, chest width; 22, hip width; 23, heart girth; 24, cranial neck circumference; 25, caudal neck circumference; 26, forehead circumference; 27, nasal bridge circumference; 28, forearm circumference; 29, knee circumference; 30, fore cannon circumference; 31, fore fetlock circumference; 32, fore pastern circumference; 33, scapulaground angle, 34, scapulohumeral angle; 35, humeroradial angle; 36, coxal-ground angle; 37, coxofemoral angle; 38, femorotibial angle; and 39, tibiometatarsal angle. Photos by Lísia Castro Krebs. 
$\mathrm{Y}_{\mathrm{ijk}}=\mu+\mathrm{S}_{\mathrm{i}}+\operatorname{COV}(\text { Age })_{\mathrm{j}}+\varepsilon_{\mathrm{ijk}}$, where $\mu$ is the overall mean; $\mathrm{S}$ is the fixed effect of sex, in two levels; Age is the covariate age (months), in $\mathrm{j}$ levels; and $\varepsilon$ is the random error.

For the multivariate analysis, Fisher's linear discriminant function was performed by applying the lda function of the MVar package of the RStudio software (Faraway, 2014), in order to obtain linear equations to classify the horses into male and female based on the linear, circumferential, and angular measurements. After the weighting coefficients were obtained, the horses were grouped by sex.

The discriminant analysis methodology is based on obtaining equations of type: $Y_{i}=\beta_{0}+\beta_{1} X_{1}+\beta_{2} X_{2}+\beta_{i} X_{i}$, where $\beta_{0}$ is a constant, $\beta_{i}$ refers to the weighting coefficients associated with the $X_{i}$ variables in the equation, and $\mathrm{Y}_{\mathrm{i}}$ is the classification of animal $\mathrm{i}$ under analysis. The $\beta_{\mathrm{i}}$ coefficients were obtained according to the grouping criterion (sex). After the weighting coefficients were obtained, the equation that provided the highest index was used to determine the group to which the horse belonged (Murtagh \& Heck, 2012).

\section{Results and Discussion}

Regarding the linear traits, the measurements of wither height, croup height, ear length, neck length, fore cannon length, fore pastern length, leg length, shoulder-fetlock distance, sternum-ground distance, chest width, and hip width differed $(p<0.05)$ between males and females (Table 1).

Wither height and croup height revealed sexual dimorphism $(p<0.05)$, with higher means for the males. These results are in agreement with the standard of the breed, which recommends that males should be taller than females, with respective minimum wither heights of 1.52 and $1.45 \mathrm{~m}$ (ABCCCampolina, 2018).

McManus et al. (2005), Boujenane et al. (2008), Pinto et al. (2008), Lucena et al. (2015), and Bussiman et al. (2018) studied the Campeiro, Arab-Barbe, Mangalarga Marchador, and Campolina breeds and also found that the measurements of wither height and croup height were in alignment with those standardized by breeder associations, as observed for the Campolina breed, with males being generally taller than females.

Table 1. Average values of the linear measurements of 84 males and 131 females of the Campolina (Equus caballus) horse breed, in Brazil, in 2016-2019.

\begin{tabular}{|c|c|c|c|c|}
\hline Morphometric measurements (m) & Male & Female & $\mathrm{SEM}^{(1)}$ & p-value \\
\hline Wither height & 1.566 & 1.533 & 0.33 & $<0.001^{*}$ \\
\hline Croup height & 1.545 & 1.528 & 0.28 & $<0.002^{*}$ \\
\hline Chest depth & 0.715 & 0.707 & 0.23 & 0.073 \\
\hline Body length & 1.609 & 1.603 & 0.37 & 0.439 \\
\hline Head length & 0.610 & 0.604 & 0.18 & 0.090 \\
\hline Ear length & 0.180 & 0.183 & 0.07 & $0.027 *$ \\
\hline Ear width & 0.651 & 0.661 & 0.05 & 0.289 \\
\hline Neck length & 0.614 & 0.599 & 0.27 & $0.006^{*}$ \\
\hline Shoulder length & 0.493 & 0.492 & 0.27 & 0.771 \\
\hline Arm length & 0.334 & 0.331 & 0.18 & 0.453 \\
\hline Forearm length & 0.447 & 0.450 & 0.14 & 0.230 \\
\hline Fore cannon length & 0.281 & 0.274 & 0.12 & $0.005^{*}$ \\
\hline Fore pastern length & 0.135 & 0.131 & 0.07 & $0.008^{*}$ \\
\hline Croup length & 0.485 & 0.490 & 0.23 & 0.271 \\
\hline Thigh length & 0.331 & 0.331 & 0.20 & 0.997 \\
\hline Leg length & 0.546 & 0.526 & 0.25 & $<0.001^{*}$ \\
\hline Hind cannon length & 0.331 & 0.332 & 0.15 & 0.906 \\
\hline Hind pastern length & 0.136 & 0.134 & 0.07 & 0.131 \\
\hline Shoulder-fetlock distance & 0.675 & 0.666 & 0.18 & $0.014 *$ \\
\hline Sternum-ground distance & 0.851 & 0.826 & 0.20 & $<0.001^{*}$ \\
\hline Chest width & 0.403 & 0.394 & 0.21 & $0.037^{*}$ \\
\hline Hip width & 0.493 & 0.504 & 0.25 & $0.022 *$ \\
\hline
\end{tabular}

(1)SEM, standard error of mean. *Significant at $\mathrm{p}<0.05$. 
Croup height was lower than wither height, as recommended for the breed (ABCCCampolina, 2018). The balance between wither height and croup height is necessary for optimal horse performance during the marcha (Lucena et al., 2015), which is a natural, symmetrical, four-beat gait with diagonal and lateral supports interspersed with triple support and no moments of suspension (Patterson et al., 2015; ABCCCampolina, 2018).

The measurement of chest depth was similar between males and females (Table 1), whereas sternum-ground distance differed by an average of $2 \mathrm{~cm}$ between the sexes $(p<0.05)$. Therefore, males were taller and had longer limbs, being classified as "far from ground", which is the name given when chest depth is lower than the sternum-ground distance; the opposite is called "near ground" (Lucena et al., 2016).

Lucena et al. (2016) observed mean sternum-ground distances of $0.87 \mathrm{~m}$ in males and of $0.82 \mathrm{~m}$ in females, as well as nonuniformity for chest depth in Campolina horses regardless of sex. These researchers suggest that the measurement of sternum-ground distance is related to limb length and chest depth, which can alter the center of gravity of the horse, influencing its stability. Boujenane et al. (2008) also observed a longer sternum-ground distance in males $(0.82 \mathrm{~m})$ than in females $(0.79 \mathrm{~m})$ of the Arab-Barbe breed. Pinto et al. (2008), however, found similarity between males and females for sternum-ground distance in Mangalarga Marchador horses.

The males exhibited a longer shoulder-fetlock distance (Table 1). This shows that forelimbs are longer in males than in females, which were differentiated by a greater fore cannon length; as a consequence, wither height was greater in males.

Hip width was larger in the mares $(\mathrm{p}<0.05)$ (Table 1), which is likely due to the physiological factor pregnancy. Likewise, in the Mangalarga Marchador breed, Pinto et al. (2008) reported a higher average hip width for females $(0.49 \mathrm{~m})$, when compared with males (0.48 m).

Head length was similar between males and females $(p>0.05)$ (Table 1). However, the mares showed a greater forehead circumference (Table 2) and ear length (Table 1). This finding is interesting for the Campolina breed considering the existence of the "best head contest" within the morphology competition. Conversely, Boujenane et al. (2008) observed that males had a longer head than females.

For the circumference measurements (Table 2), heart girth and the circumferences of cranial neck, caudal neck, forehead, forearm, fore cannon, fore fetlock, and fore pastern differed between the sexes $(p<0.05)$.

Heart girth was greater in the female Campolina horses (Table 2). Purzyc et al. (2011) found that subsequent pregnancies cause mares to withstand a greater indirect pressure on their diaphragm region, resulting in a greater arching of their ribs and, therefore, in greater heart girths as they advance in age; however, in the present study, the younger mares showed heart girth values equal to or even higher than those of females over the age of eight years. In contrast, McManus et al. (2005), Boujenane et al. (2008), Pinto et al. (2008), Purzyc et al. (2011), and Lucena et al. (2016) found a greater heart girth in males.

Table 2. Average values of the circumferential measurements of 84 males and 131 females of the Campolina (Equus caballus) horse breed, in Brazil, in 2016-2019.

\begin{tabular}{llccc}
\hline Morphometric measurements $(\mathrm{m})$ & Male & Female & SEM $^{(1)}$ & $\mathrm{p}$-value \\
\hline Heart girth & 1.799 & 1.837 & 0.83 & $0.022^{*}$ \\
Cranial neck circumference & 0.815 & 0.779 & 0.39 & $<0.001^{*}$ \\
Caudal neck circumference & 1.299 & 1.154 & 0.85 & $<0.001^{*}$ \\
Forehead circumference & 0.879 & 0.896 & 0.23 & $<0.001^{*}$ \\
Nasal bridge circumference & 0.628 & 0.630 & 0.31 & 0.704 \\
Forearm circumference & 0.330 & 0.323 & 0.14 & $0.019^{*}$ \\
Knee circumference & 0.307 & 0.310 & 0.12 & 0.296 \\
Fore cannon circumference & 0.187 & 0.195 & 0.11 & $<0.001^{*}$ \\
Fore fetlock circumference & 0.262 & 0.270 & 0.12 & $0.002^{*}$ \\
Fore pastern circumference & 0.183 & 0.192 & 0.09 & $<0.001^{*}$ \\
\hline
\end{tabular}

(1)SEM, standard error of mean. *Significant at $\mathrm{p}<0.05$. 
Males had a larger neck, both in length (Table 1) and circumference (Table 2), than females. These results are interesting because a more developed neck can be considered a characteristic of horse masculinity.

Fore cannon, fore fetlock, and fore pastern circumferences were greater in the mares (Table 2). These results disagree with those reported by Boujenane et al. (2008), Pinto et al. (2008) and Purzyc et al. (2011), who observed that males exhibited higher values for these measurements.

The angular measurements that characterized the Campolina horses as males and females were: scapulohumeral angle, coxal-ground angle, and femorotibial angle $(\mathrm{p}<0.05)$ (Table 3$)$.

Overall, the male Campolina horses had lower angular values than the females (Table 3). The scapulohumeral angle values obtained for the horses in the present study were lower than those found by Cabral et al. (2004) and Pinto et al. (2008) for adult Mangalarga Marchador horses, which also have the marcha gait.

The lower scapulohumeral angle means observed in the males may be due to the greater selection pressure to which the stallions are subjected. According to Pinto et al. (2008), the shoulder slope is directly associated with the quality of the marcha movement, suggesting that more inclined shoulders indicate a lower angulation of the thoracic limb and, therefore, a better quality of the movement. However, a very acute scapulohumeral angle can affect stride length (Hodgson et al., 2013).

The obtained coxal-ground angle measurements indicate that the Campolina horses have a sloping croup (Table 3). The observed mean coxal-ground angles are close to those reported by Holmström et al. (1994), who evaluated male Swedish Warmblood horses and found angles ranging from 29.5 to $32.5^{\circ}$.
Higher coxal-ground angles may provide a greater mechanical advantage for muscle contraction, resulting in pelvic members with a greater weight support capacity, elasticity, and propulsion. In addition, they may indicate an increase in stride frequency (Holmström et al., 1994; Hodgson et al., 2013; Santiago et al., 2014; Padilha et al., 2017).

When the discriminant analysis was performed for the classification by sex, for the linear measurements, 14 mares were classified as males, representing an error percentage of $10.69 \%$, and 22 males were classified as females, indicating an error of $26.19 \%$ (Table 4 and Figure 2 A). This revealed that, for these measurements, a higher number of males were classified as females. This can be explained by the reduction in the morphometric measurements of the Campolina horses, especially of the stallions, encouraged by ABCCCampolina according to the data obtained by Sousa et al. (2018).

For the circumferential measurements (Table 5 and Figure 2 B), 21 females were categorized as males, indicating a classification error of $16.03 \%$, and 10 males were classified as females, showing a classification error of $11.90 \%$. These results indicate that lower classification errors were obtained for males.

Based on the angular measurements, 26 females were categorized as males and 32 males as females, with respective classification errors of 19.85 and $38.10 \%$ (Table 6 and Figure 2 C). However, only three of the angular measurements showed sexual dimorphism, and, in this category, the highest classification error was observed for males. This is in agreement with the lower accuracy, sensitivity, and specificity values of the classification by the generated equation, when compared with the linear and circumferential measurements.

Table 3. Average values of the angular measurements of 84 males and 131 females of the Campolina (Equus caballus) horse breed, in Brazil, in 2016-2019.

\begin{tabular}{|c|c|c|c|c|}
\hline Morphometric measurements $\left({ }^{\circ}\right)$ & Male & Female & SEM $^{(1)}$ & p-value \\
\hline Scapula-ground angle & 68.57 & 68.15 & 0.32 & 0.520 \\
\hline Scapulohumeral angle & 89.60 & 87.22 & 0.35 & $<0.001^{*}$ \\
\hline Humeroradial angle & 142.86 & 141.66 & 0.34 & 0.081 \\
\hline Coxal-ground angle & 27.62 & 31.98 & 0.33 & $<0.001 *$ \\
\hline Coxofemoral angle & 87.17 & 88.34 & 0.46 & 0.241 \\
\hline Femorotibial angle & 110.54 & 113.09 & 0.43 & $<0.001 *$ \\
\hline Tibiometatarsal angle & 141.73 & 140.89 & 0.26 & 0.109 \\
\hline
\end{tabular}

(1)SEM, standard error of mean. *Significant at $\mathrm{p}<0.05$. 
Pinto et al. (2008) reported that the angles in Mangalarga Marchador horses were remarkably similar between both sexes. However, the authors found lower classification errors of $3.5 \%$ for females and $12 \%$ for males for linear and angular measurements, respectively.

Despite the bias in the obtained classification, the metrics of accuracy, sensitivity, and specificity reinforce the robustness of the analysis and the predictive power of the equations generated for the classification of sexual dimorphism (Tedeschi, 2006). The values of these metrics are above $70 \%$ (Tables 4 , 5 , and 6), which is satisfactory for classification by the discriminant analysis (Purzyc et al., 2011).

Of the 39 morphometric measurements evaluated in the present study, 22 were responsible for sexual

Table 4. Classification of the Campolina (Equus caballus) horse breed according to discriminant analyses, sex, and linear measurements, in Brazil, in 2016-2019 ${ }^{(1)}$.

\begin{tabular}{lccc}
\hline Item & Female & Male & Total \\
\hline Number of females & 117 & 14 & 131 \\
Classification (\%) & 89.31 & $10.69^{(2)}$ & 100 \\
Number of males & 22 & 62 & 84 \\
Classification (\%) & $26.19^{(2)}$ & 73.81 & 100 \\
\hline
\end{tabular}

${ }^{(1)} \mathrm{Y}=13.395+0.86 \mathrm{X}_{1}-0.04 \mathrm{X}_{2}-0.57 \mathrm{X}_{3}+0.07 \mathrm{X}_{4}+0.08 \mathrm{X}_{5}+0.40 \mathrm{X}_{6}+$ $0.07 \mathrm{X}_{7}+0.02 \mathrm{X}_{8}+0.15 \mathrm{X}_{9}+0.12 \mathrm{X}_{10}-0.17 \mathrm{X}_{11}$, where $\mathrm{X}_{1}$ is wither height, $X_{2}$ is croup height, $X_{3}$ is ear length, $X_{4}$ is neck length, $X_{5}$ is fore cannon length, $X_{6}$ is fore pastern length, $X_{7}$ is leg length, $X_{8}$ is shoulder-fetlock distance, $X_{9}$ is sternum-ground distance, $X_{10}$ is chest width, and $X_{11}$ is hip width. Accuracy $(\%)=83.26$; sensitivity $(\%)=89.31$; and specificity $(\%)=73.81 .{ }^{(2)}$ Classification error. dimorphism in the Campolina horses. The mean values of the traits were $59 \%$ higher in the males than in the females. Mares only showed higher means for ear length, hip width, heart girth, forehead circumference, fore cannon circumference, fore fetlock circumference, fore pastern circumference, coxal-ground angle, and femorotibial angle.

The classification of sexual dimorphism in Campolina horses through morphometric assessments showed to be more effective when using the linear and circumferential measurements (Figure $2 \mathrm{~A}$ and B) instead of the angular measurements. This is because, in the first two, females and males were grouped in a delimited region and exhibited different values, indicating a greater sexual dimorphism. For the angular measurements (Figure $2 \mathrm{C}$ ), equal values were obtained between the sexes and a greater range of classification was observed. The delimitation of the region in Figure 2 and the greater differentiation of sex groups are related to better accuracy, sensitivity, and specificity values.

It is suggested that ABCCCampolina (Sousa et al., 2018) adopts a higher number of linear measurements and some circumferential measurements as a breed standard for distinguishing males and females. Neck length, heart girth, fore cannon circumference, and hip width are recommended. Additionally, the sternum-ground and shoulder-fetlock distances should be included in the standard. The adoption of these measures will result in a greater sexual dimorphism in the breed.
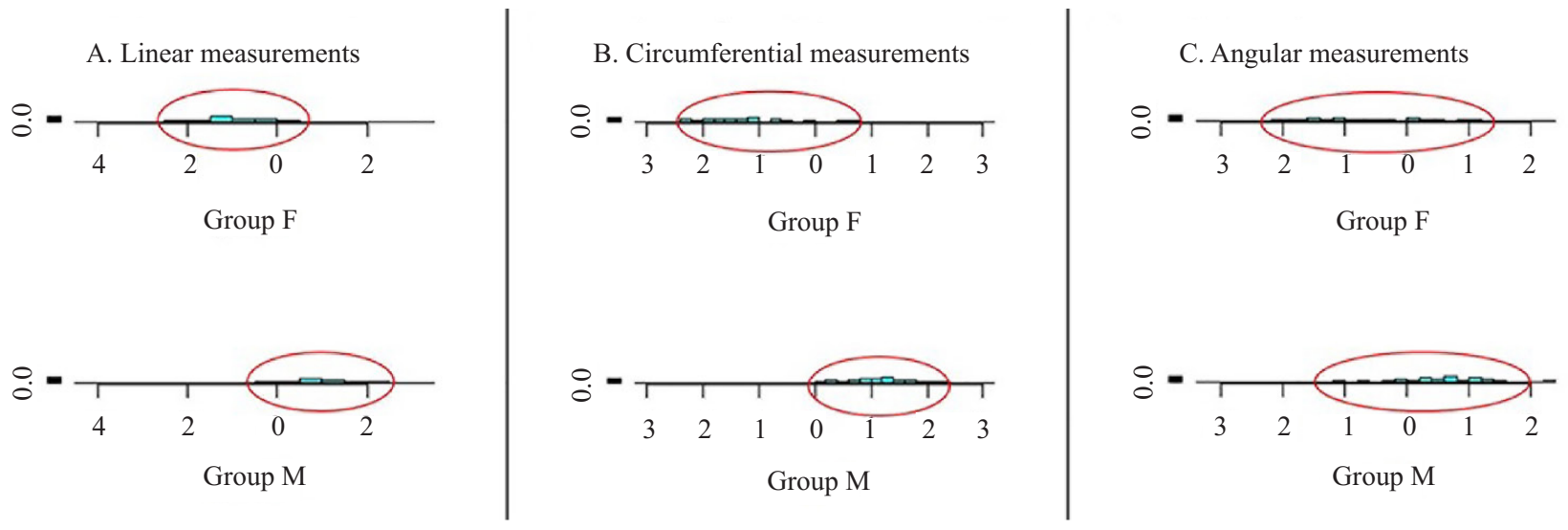

Figure 2. Classification of the morphometric measurements of the Campolina (Equus caballus) horse breed in Brazil according to sex. F, females (131); and M, males (84). Red circles indicate the classification of the horses according to the predicted values of accuracy, specificity, and sensitivity of the discriminant functions. 
Table 5. Classification of the Campolina (Equus caballus) horse breed according to discriminant analyses, sex, and circumferential measurements, in Brazil, in 2016-2019 ${ }^{(1)}$.

\begin{tabular}{lccc}
\hline Item & Female & Male & Total \\
\hline Number of females & 110 & 21 & 131 \\
Classification (\%) & 83.97 & $16.03^{(2)}$ & 100 \\
Number of males & 10 & 74 & 84 \\
Classification (\%) & $11.90^{(2)}$ & 88.09 & 100 \\
\hline
\end{tabular}

${ }^{(1)} \mathrm{Y}=-5.806-0.021 \mathrm{X}_{1}+0.022 \mathrm{X}_{2}+0.095 \mathrm{X}_{3}-0.122 \mathrm{X}_{4}-0.022 \mathrm{X}_{5}-0.286 \mathrm{X}_{6}+$ $0.062 \mathrm{X}_{7}-0.275 \mathrm{X}_{8}$, where $\mathrm{X}_{1}$ is heart girth, $\mathrm{X}_{2}$ is cranial neck circumference, $\mathrm{X}_{3}$ is caudal neck circumference, $\mathrm{X}_{4}$ is forehead circumference, $\mathrm{X}_{5}$ is forearm circumference, $X_{6}$ is fore cannon circumference, $X_{7}$ is fore fetlock circumference, and $\mathrm{X}_{8}$ is fore pastern circumference. Accuracy $(\%)=85.58$; sensitivity $(\%)=83.97$; and specificity $(\%)=88.10$. ${ }^{(2)}$ Classification error.

Table 6. Classification of the Campolina (Equus caballus) horse breed according to discriminant analyses, sex, and angular measurements, in Brazil, in 2016-2019 ${ }^{(1)}$.

\begin{tabular}{lccc}
\hline Item & Female & Male & Total \\
\hline Number of females & 105 & 26 & 131 \\
Classification (\%) & 80.15 & $19.85^{(2)}$ & 100 \\
Number of males & 32 & 52 & 84 \\
Classification (\%) & $38.10^{(2)}$ & 61.90 & 100 \\
\hline
\end{tabular}

${ }^{(1)} \mathrm{Y}=6.254+0.078 \mathrm{X}_{1}-0.212 \mathrm{X}_{2}-0.054 \mathrm{X}_{3}$, where $\mathrm{X}_{1}$ is the scapulohumeral angle, $X_{2}$ is the coxal-ground angle, and $X_{3}$ is the femorotibial angle. Accuracy $(\%)=73.02$; sensitivity $(\%)=80.15$; and specificity $(\%)=61.90$. ${ }^{(2)}$ Classification error

The evaluation of sexual dimorphism will make it possible to improve the measurement standard adopted by breeder associations and used by technicians and judges.

\section{Conclusions}

1. Of the 39 morphometric measurements evaluated, 22 are responsible for sexual dimorphism in the Campolina (Equus caballus) horse breed.

2. The circumferential (85.58\%) and linear (83.26\%) measurements of the Campolina horse allow a more assertive classification to determine sexual dimorphism.

3. Angular measurements show greater classification errors regarding the gender of the horses.

\section{Acknowledgments}

To those responsible for and to the employees of the Oratório farm, for support and encouragement; to Coordenação de Aperfeiçoamento de Pessoal de Nível Superior (Capes), for financing, in part, this study (Finance Code 001); to Conselho Nacional de Desenvolvimento Científico e Tecnológico (CNPq), for financial support (process number 428383/2016-5) and scientific initiation scholarship; and to Fundação de Amparo à Pesquisa do Estado do Rio de Janeiro (Faperj), for scientific initiation scholarship.

\section{References}

ABCCCampolina. Associação Brasileira dos Criadores do Cavalo Campolina. Regulamento do Serviço do Registro Genealógico do Cavalo Campolina - SRGCC. 2018. Available at: <http:// www.campolina.org.br/pdfs/regulamentos/RegulamentoMapa. pdf>. Accessed on: Apr. 22020.

ABCCCrioulos. Associação Brasileira de Criadores de Cavalos Crioulos. Regulamento do Registro Genealógico da Raça Equina Crioula. 2020. Available at: $<$ https://www.cavalocrioulo. org.br/admin/assets/upload/regulamentos/3696409691.pdf >. Accessed on: Apr. 162020.

ABCCH. Associação Brasileira de Criadores do Cavalo de Hipismo. Regulamento S.B.B.C.H. 2020. Available at: <https://abcch.com.br/arq/comunicado/ REGULAMENTO_201123170713Regulamento_12538788_ Regulamento_Registro_Genealogico_ABCCH__PARA_ APROVACAO.pdf $>$. Acessed on: July 12021.

ABCCMM. Associação Brasileira dos Criadores do Cavalo Mangalarga Marchador. Regulamento do Serviço de Registro Genealógico do Cavalo Mangalarga Marchador. 2019. Available at: <http://leia.abccmm.org.br/portal/regulamentos/ regulamentosrg.pdf $>$. Accessed on: Apr. 242021.

ABCCRMANGALARGA. Associação Brasileira de Criadores de Cavalos da Raça Mangalarga. Regulamento do Serviço de Registro Genealógico. 2020. Available at: <https://www. cavalomangalarga.com.br/documentos/regulamento_srg_2020. pdf $>$. Accessed on: Apr. 242021.

BOUJENANE, I.; TOUATI, I.; MACHMOUM, M. Mensurations corporelles des chevaux Arabe-Barbes au Maroc. Revue de Médecine Vétérinaire, v.159, p.144-149, 2008.

BUSSIMAN, F. de O.; PEREZ, B. da C.; VENTURA, R.V.; SILVA, F.F. e; PEIXOTO, M.G.C.D.; VIZONÁ, R.G.; MATTOS, E.C.; FERRAZ, J.B.S.; ELER, J.P.; CURI, R.A.; BALIEIRO, J.C. de $\mathrm{C}$. Genetic analysis of morphological and functional traits in Campolina horses using Bayesian multi-trait model. Livestock Science, v.216, p.119-129, 2018. DOI: https://doi.org/10.1016/j. livsci.2018.08.002

CABRAL, G.C.; ALMEIDA, F.Q. de; AZEVEDO, P.C.N. de; QUIRINO, C.R.; SANTOS, E.M.; CORASSA, A.; PINTO, L.F.B. Avaliação morfométrica de eqüinos da raça Mangalarga Marchador: medidas angulares. Revista Brasileira de Zootecnia, v.33, p.1790-1797, 2004. Supl. 1. DOI: https://doi.org/10.1590/ S1516-35982004000700017. 
FARAWAY, J.J. Linear models with R. $2^{\text {nd }}$ ed. Boca Raton: Chapman and Hall/CRC, 2014. 286p.

HÄRDLE, W.K.; SIMAR, L. Discriminant analysis. In: HÄRDLE, W.K.; SIMAR, L. Applied Multivariate Statistical Analysis. $4^{\text {th }}$ ed. Berlin: Springer, 2015. p.407-424. DOI: https://doi.org/10.1007/978-3-662-45171-7_14.

HINTZ, H.F.; HINTZ, R.L.; VAN VLECK, L.D. Growth rate of Thoroughbreds. Effect of age of dam, year and month of birth, and sex of foal. Journal of Animal Science, v.48, p.480-487, 1979. DOI: https://doi.org/10.2527/jas1979.483480x.

HODGSON, D.R.; MCKEEVER, K.; MCGOWAN, C.M. [Ed.]. The athletic horse: principles and practice of equine sports medicine. $2^{\text {nd }}$ ed. St. Louis: Elsevier, 2013.

HOLMSTRÖM, M.; FREDRICSON, I.; DREVEMO, S. Biokinematic differences between riding horses judged as good and poor at the trot. Equine Veterinary Journal, v.26, p.51-56, 1994. DOI: https://doi.org/10.1111/j.2042-3306.1994.tb04874.x.

LUCENA, J.E.C.; VIANNA, S.A. de B.; BERBARI NETO, F.; SALES FILHO, R.L.M.; DINIZ, W.J. da S. Estudo comparativo das proporções morfométricas entre garanhões e castrados da raça Campolina. Semina: Ciências Agrárias, v.36, p.353-366, 2015. DOI: https://doi.org/10.5433/1679-0359.2015v36n1p353.

LUCENA, J.E.C.; VIANNA, S.A.B.; BERBARI NETO, F.; SALES FILHO, R.L.M.; DINIZ, W.J.S. Caracterização morfométrica de fêmeas, garanhões e castrados da raça Campolina baseada em índices. Arquivo Brasileiro de Medicina Veterinária e Zootecnia, v.68, p.431-438, 2016. DOI: https://doi.org/10.1590/1678-4162-8016.

MCMANUS, C.; FALCÃO, R.A.; SPRITZE, A.; COSTA, D.; LOUVANDINI, H.; DIAS, L.T.; TEIXEIRA, R. de A.; REZENDE, M.J. de M.; GARCIA, J.A.S. Caracterização morfológica de eqüinos da raça Campeiro. Revista Brasileira de Zootecnia, v.34, p.1553-1562, 2005.

MURTAGH, F.; HECK, A. Multivariate data analysis. Dordrecht: Springer, 2012.

PADILHA, F.G.F.; ANDRADE, A.M. de; FONSECA, A.B.M.; GODOI, F.N. de; ALMEIDA, F.Q. de; FERREIRA, A.M.R. Morphometric measurements and animal-performance indices in a study of racial forms of Brazilian Sport Horses undergoing training for eventing. Revista Brasileira de Zootecnia, v.46, p.2532, 2017. DOI: https://doi.org/10.1590/s1806-92902017000100005.

PATTERSON, L.; STAIGER, E.A.; BROOKS, S.A. DMRT3 is associated with gait type in Mangalarga Marchador horses, but does not control gait ability. Animal Genetics, v.46, p.213-215, 2015. DOI: https://doi.org/10.1111/age.12273.

PINTO, L.F.B.; ALMEIDA, F.Q. de; QUIRINO, C.R.; AZEVEDO, P.C.N. de; CABRAL, G.C.; SANTOS, E.M.; CORASSA, A. Evaluation of the sexual dimorphism in Mangalarga Marchador horses using discriminant analysis. Livestock Science, v.119, p.161-166, 2008. DOI: https://doi.org/10.1016/j.livsci.2008.03.014.

PURZYC, H.; KOBRYŃCZUK, F.; BOJARSKI, J. Sexual dimorphism in Hucul horses using discriminant analysis. Animal, v.5, p.506-511, 2011. DOI: https://doi.org/10.1017/ S1751731110002223.

SANTIAGO, J.M.; REZENDE, A.S.C.; LANA, Â.M.Q.; FONSECA, M.G.; ABRANTES, R.G.P.; LAGE, J.; ANDRADE, J.M.; RESENDE, T.M. Comparação entre as medidas morfométricas de equinos Mangalarga Marchador de marcha batida e marcha picada. Arquivo Brasileiro de Medicina Veterinária e Zootecnia, v.66, p.635-639, 2014. DOI: https://doi.org/10.1590/1678-41626870.

SOUSA, A.S. de; JESUS, I.I.C. de; OLIVEIRA, C.A. de A.; COSTA, R.B.; GODOI, F.N. de. How is the morphometry of stallions and mares show-winning and nonwinning Campolina Brazilian breed with batida and picada gaits? Journal of Equine Veterinary Science, v.64, p.34-40, 2018. DOI: https://doi.org/10.1016/j.jevs.2018.02.012.

TAKAENDENGAN, B.J.; NOOR, R.R.; ADIANI, S. Morphometric characterization of Minahasa horse for breeding and conservation purposes. Media Peternakan, v.34, p.99-104, 2011. DOI: https://doi.org/10.5398/medpet.2011.34.2.99.

TEDESCHI, L.O. Assessment of the adequacy of mathematical models. Agricultural Systems, v.89, p.225-247, 2006. DOI: https://doi.org/10.1016/j.agsy.2005.11.004.

VAŽIĆ, B.; SARAJLIĆ, Đ.; ROGIĆ, B. Morphometric characterization of the Lipizzaner horse breed in the stud „Vučijak“. Biotechnology in Animal Husbandry, v.32, p.219227, 2016. DOI: https://doi.org/10.2298/BAH1602219V. 